\title{
Penegakan Hukum Lingkungan Terhadap Analisis Dampak Lingkungan (AMDAL) Reklamasi Pantai di Kota Bandar Lampung
}

\author{
Eka Deviani
}

Dosen Bagian Hukum Administrasi Negara FH Universitas Lampung

\begin{abstract}
Abstrak
Tujuan penelitian ini adalah untuk mengetahui penegakan hukum lingkungan terhadap Analisis Mengenai Dampak Lingkungan (AMDAL) reklamasi pantai di Kota Bandar Lampung, dan faktor-faktor yang menjadi penghambat dalam penegakan hukum terhadap AMDAL reklamasi pantai di Kota Bandar Lampung. Berdasarkan hasil penelitian dokumen dan wawancara ditemukan bahwa penegakan hukum lingkungan yang dilakukan di Bandar Lampung adalah mencakup penegakan hukum pidana (code penal), perdata dan administrasi. Adapun faktor-faktor yang menjadi penghambat adalah faktor Hukum, faktor Aparat (Pemerintah) dan faktor Ekonomi.
\end{abstract}

Kata Kunci : AMDAL, reklamasi pantai, dan faktor penghambat.

\section{PENDAHULUAN}

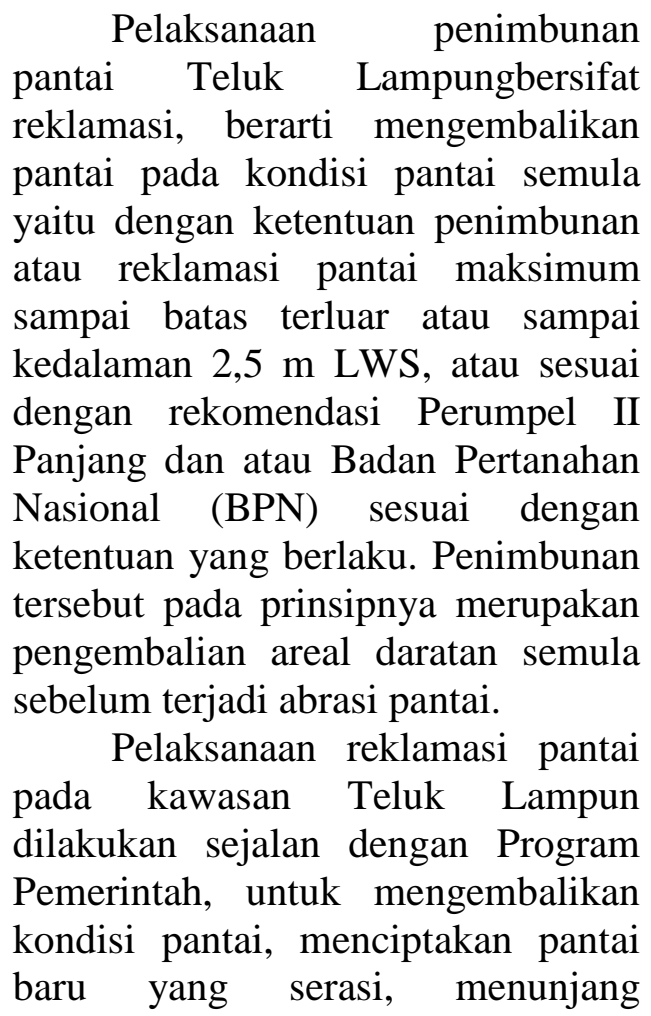

pembangunan pariwisata dan perekonomian daerah.

Reklamasi pantai pada dasarnya akan menimbulkan dampak perubahan garis pantai dan lingkungan yang akan berpengaruh terhadap keselamatan lalu lintas kapal maupun kepentingan instansi terkait lainnya. Oleh karena reklamasi pantai secara langsung akan menimbulkan perubahan lingkungan, maka pemberian izin reklamasi pantai harus dilengkapi dengan Rencana Pengelolaan Lingkungan (RKL) dan Rencana Pemantauan Lingkungan (RPL) yang merupakan produk akhir dari Analisis Mengenai Dampak Lingkungan (AMDAL).

Dalam kenyataan masih banyak perusahaan-perusahaan baik yang bergerak di bidang pariwisata ataupun bisnis melakukan reklamasi pantai tanpa memiliki RKL dan RPL. 
Hal ini terlihat dengan adanya beberapa Surat Keputusan Gubernur mengenai pemberian izin reklamasi pantai terhadap perusahaanperusahaan yang ada tidak dilengkapi dengan RKL dan RPL. Jadi RKL dan RPL yang merupakan produk akhir dari Amdal hanya sebagai alat kelengkapan admintrasi, karena dalam hal ini yang terjadi izin penimbunan pantai dahulu baru RKL dan RPL, yang seharusnya RKL dan RPL dahul dan izin-izin lain selanjutnya izin penimbunan.

Fungsi RKL dan RPL yang merupakan produk akhir dari Amdal terhadap reklamasi pada dasarnya adalah untuk mengendalikan perusakan lingkungan akibat adanya reklamasi pantai. Oleh karena itu pemberian izin penimbunan terhadap reklamasi pantai harus dilengkapi RKL dan RPL. Berdasarkan hal tersebut maka penegakan hukum perlu diterapkan baik penegakan hukum pidana, perdata maupun administrasi, terhadap perusahaanperusahaan yang menjalankan usahanya dengan melakukan reklamasi pantai tanpa dilengkapi RKL dan RPL. Dengan acuan penegakan hukum tersebut adalah UU RI No.32 Th.2009 tentang perlindungan dan pengolahan lingkungan hidup, PP RI No.27 Th.1999 tentang analisis dampak lingkungan hidup, Kepres RI No.10 Th.2000 tentang pengendalian dampak lingkungan. Penegakan hukum tersebut diperlukan agar para pengusaha tidak sewenang-wenang melakukan reklamasi pantai tanpa memikirkan dampaknya terhadap perusakan lingkungan pantai.

Pelaksanaan penimbunan atau reklamasi pantai di Kota Bandar
Lampung selain mempunyai dampak negatif, juga mempunyai dampak positif, diantaranya terdapat banyak investor yang akan menanamkan modalnya untuk mendirikan perusahaan di Bandar Lampung terutama di daerah Teluk Lampung, sehingga menyebabkan tersedianya banyak lapangan pekerjaan bagi warga setempat yang ingin bekerja pada perusahaan yang melakukan penimbunan/reklamasi pantai yaitu sehingga mereka tidak menganggur.

Selain itu dampak positif dari penimbunan/reklamasi pantai yaitu meningkatkan jumlah Pendapatan Asli Daerah (PAD) Provinsi Lampung, karena banyak investor/pengusaha yang menanamkan modalnya serta mendirikan perusahaan di Bandar Lampung.

Berdasarkan identifikasi masalah tersebut permasalahan dirumuskan sebagai berikut :

1. Bagaimana penegakan hukum lingkungan terhadap Analisis Mengenai Dampak Lingkungan (AMDAL) reklamasi pantai di Kota Bandar Lampung?

2. Faktor-faktor apakah yang menjadi penghambat dalam penegakan hukum terhadap Analisis Mengenai Dampak Lingkungan (AMDAL) reklamasi pantai di Kota Bandar Lampung?

\section{METODE PENELITIAN}

Penelitian ini merupakan penelitian normative dan empiris. Pendekatan yuridis, ditujukan untuk mengkaji keterkaitan peraturan perundang-undangan lingkungan hidup antara satu dengan yang lain dalam hubungannya dengan 
penegakan hukum lingkungan. Pendekatan empiris dilakukan dengan cara melihat atau mempelajari kenyataan-kenyataan hukum dalam bentuk perilaku, pendapat, perasaan, sikap secara nyata.

\section{HASIL PENELITIAN DAN PEMBAHASAN}

3.1.Penegakan Hukum Lingkungan Terhadap Analisis Mengenai Dampak Lingkungan (AMDAL) Reklamasi Pantai di Kota Bandar Lampung

\section{a. Penegakan Hukum Pidana}

Didalam rangka penegakan hukum lingkungan dilihat dari sudut hukum pidana, maka perlu pemrakarsa dalam hal ini pengusaha dapat dikenakan denda atau kurungan bilamana melakukan kegiatan tidak memenuhi salah satu syarat perizinan dalam hal ini termasuk proses AMDAL.

Konsultan AMDAL dapat dikenakan sanksi pidana apabila studi AMDAL (data dan informasi) yang disampaikan tidak berdasarkan studi yang benar/palsu, (misal AMDAL fiktif). Hal ini dibuktikan dengan kesaksian ahli di pengadilan.

Dipertegas dalam UU RI No.32 Th.2009 tentang perlindungan dan pengelolaan lingkungan hidup terhadapa sangsi pidana/ketentuan pidana pada Bab XV pasal $97 \mathrm{~s} / \mathrm{d}$ 120.

\section{b. Penegakan Hukum Perdata}

Keterkaitan pengelolaan lingkungan hidup terhadap masalah penegakan hukum AMDAL
Reklamasi Pantai di Kota Bandar Lampung dilihat dari sudut hukum perdata, mengacu pada ajaran mengenai perbuatan melawan hukum pasal 1365 Kitab Undang-undang Hukum Perdata (KUHPdt). Menurut Pasal 1365 KUHPdt, perbuatan melawan hukum yang membawa kerugian kepada orang lain, mewajibkan orang yang karena salahnya menimbulkan kerugian itu, untuk mengganti kerugian.

Unsur-unsur Pasal 1365 KUHPdt yang harus dibuktikan ialah:

a. Perbuatan tersebut harus melawan hukum;

b. Pelaku harus bersalah

c. Ada kerugian

d. Ada hubungan sebab akibat antara perbuatan dengan kerugian.

Selanjutnya penggunaan hukum pidana dan hukum administrasi dalam rangka penegakan hukum di bidang AMDAL Reklamasi Pantai ini terutama bertujuan agar tercapai ketertiban kehidupan masyarakat secara keseluruhan, sedangkan hukum perdata bertujuan untuk memberikan perlindungan kepentingan warga masyarakat secara individual dalam hubungan dengan warga masyarakat.

\section{c. Penegakan Hukum Administrasi}

Berdasarkan hasil wawancara dengan Kepala Sub Bidang AMDAL dan Kepala Bidang Konservasi, Rehabilitasi Lingkungan Hidup dan Mitra Lingkungan Bapedalda Provinsi Lampung, maka terhadap perusahaan yang tidak/belum 
memiliki izin AMDAL tetapi sudah melakukan penimbunan/reklamasi pantai dan sudah menjalankan usahanya dapat dikenakan sanksi administrasi.

Jika terjadi pelanggaran peraturan, misalnya mengenai izin AMDAL dalam rangka penimbunan/reklamasi pantai, maka langkah represif untuk memaksakan kepatuhan dilakukan melalui penerapan sanksi administrasi, beberapa jenis sanksi administrasi sebagai sarana penegakan hukum lingkungan adalah :

a. Paksaan pemerintah (bestuursdwang)

b. Uang paksa (publiekrechtelijke dwangsom)

c. Penutupan tempat usaha (slutting van een inrichting)

d. Penghentian kegiatan mesin perusahaan (buitengebruikstelling van een roastel);

e. Pencabutan izin (Muhammad Akib, 2000 : 72).

Dipertegas dalam UU No.32 Th. 2009 tentang perlindungan dan pengelolaan lingkungan hidup terhadap sanksi administrative pada Pasal 76 s/d 83

\subsection{Faktor-Faktor Penghambat Penegakan Hukum Terhadap Analisis Mengenai Dampak Lingkungan (AMDAL) Reklamasi Pantai Di Bandar Lampung.}

Faktor penghambat penegakan hukum terhadap pelaksanaan reklamasi pantai yang telah lama dilaksanakan yaitu sejak tahun 1983, disebabkan oleh beberapa faktor, seperti faktor hukum yakni kurang tegasnya penerapan sangsi oleh instansi terkait dalam penyelenggaraan reklamasi pantai terhadap perusahaan yang tidak melaksanakan kewajiban sebagaimana mestinya yang ditentukan di dalam surat keputusan pemberian izin penimbunan pantai merupakan kendala penyelenggaraan reklamasi pantai.

Tidak adanya peraturan yang dalam hal ini Perda yang secara khusus mengatur tentang reklamasi pantai, sehingga penegakan hukum AMDAL reklamasi pantai terhadap perusahaan yang tidak memiliki izin AMDAL serta melakukan pencemaran dan perusakan lingkungan akan sulit ditegakkan.

Apabila perkara pencemaran dan perusakan lingkungan hidup diselesaikan melalui Peradilan Tata Usaha Negara, maka kemungkinan pengajuan gugatan pencabutan izin ke PTUN akan menemui kendala, antara lain karena panjangnya alur penyelesaian sengketa dan tidak jelasnya tenggang waktu pengajuan gugatan bagi pihak ke tiga.

Selain faktor hukum, faktor aparat pemerintah yang dalam hal ini yaitu koordinasi antar instansi yang terkait dalam penyelenggaraan reklamasi pantai belum mantap karna secara teknis kewenangan ada pada masing-masing instansi pemberi izin dengan berbagai keterbatannya.

Faktor ekonomi juga menyebabkan hukum tidak dapat ditegakkan sebagaimana mestinya. Mislanya apabila perusahaan tersebut ditutup atau di cabut izin usahanya, maka dalam hal ini akan mengakibatkan puluhan bahkan ratusan buruh akan menganggur 
(kehilangan pekerjaan) dan perusahaan akan menderita kerugian yang sangat besar sehingga keadaan ekonomi akan memburuk.

Selain faktor-faktor penghambat penegakan hukum AMDAL reklamasi pantai di Kota Bandar Lampung, berdasarkan hasil penelitian di lapangan terdapat pula faktor-faktor penghambat dalam penyelenggaraan reklamasi pantai antara lain :

1. Luasnya pantai yang direklamasi oleh perusahaan, merupakan kendala dalam penyelenggaraan reklamasi pantai, apalagi bila tidak ditunjang dengan dana yang cukup besar serta peralatan yang canggih dan lengkap maka sebagian masyarakat akan terhambat.

2. Adanya sebagian masyarakat yang masih belum bersedia meninggalkan lokasi yang akan di timbun, karena alasan dekat dengan tempat usaha.

3. Hambatan lain yang dihadapi selama ini lebih banyak menyangkut pemindahan rumah, misalnya sudah dibayar kemudian kembali ketempat asalnya. Dalam soal reklamasi tidak ada istilah ke tempat asalnya, yang ada adalah sistem kerja sama dengan pihak terkait dengan menggunakan pendekatan. Oleh karena itu daerah-daerah reklamasi yang bermasalah dihindari dahulu, terutama yang menyangkut ganti rugi.

\section{SIMPULAN}

Berdasarkan uraian-uraian tersebut, dapat disimpulkan sebagai berikut :

1. Bahwa dalam rangka penegakan hukum lingkungan dilihat dari sudut hukum pidana, maka pemrakarsa dalam hal ini pengusaha dapat dikenakan denda atau kurungan bilamana melakukan kegiatan tidak memenuhi salah satu syarat perizinan dalam hal ini termasuk proses AMDAL. Sedangkan perusahaan yang tidak/belum memiliki izin AMDAL tetapi sudah melakukan penimbunan/reklamasi pantai dan sudah menjalankan usahanya dapat dikenakan sanksi administrasi sesuai dengan UU No.32 Th. 2009 Terhadap sanksi administrasi.

2. Faktor-faktor penghambat dalam rangka penegakan hukum terhadap AMDAL reklamasi pantai di Kota Bandar Lampung adalah meliputi Faktor Hukum, Faktor Aparat (Pemerintah) dan faktor Ekonomi.

\section{DAFTAR PUSTAKA}

Akib, Muhammad, 2000. Justicia Pengendalian Pencemaran dan Perusakan Lingkungan (Kajian dari Aspek Hukum Lingkungan Administrasi). Fakultas Hukum Universitas Lampung.

Arief, Barda Nawawi. 2000. Hukum Penegakan Lingkungan Hukum Dan Kebijakan Penanggulangan Kejahatan. Citra Aditya Bakti. Bandung. 
Hardjasoemantri, Koesnadi. 2000. Hukum Tata Lingkungan. Gadjah Mada University Press. Yogyakarta.

Mamudji, Sri dan Soerdjono Soekanto. 1995. Penelitian Hukum Normatif Suatu Tinjauan Singkat. Raja Grafindo Persada. Jakarta.

Mechsan, Sudirman. 1997. Justicia. Reklamasi Pantai Untuk Keperluan Pembangunan dan Kaitannya Dengan Pendaftaran Tanah. Fakultas Hukum. Universitas Lampung.

Nurhalim, H. 1999. Pengertian dan Dasar-Dasar $A M D A L$ Pelatihan Pengelolaan Wilayah Pesisir dan Lautan. Pekan Baru, 28 Juni s.d 7 Juli 1999

Silalahi, Daud. 1995. Penelitian Aspek-Aspek Hukum Tentang Ketentuan AMDAL Dalam Pembangunan Industri. Bahan Pembinaan Hukum Nasional Departemen Kehakiman.

Soemartono, R.M. Gatot P. 1996. Hukum Lingkungan Indonesia. Sinar Grafika, Jakarta.

Laporan Akhir Rencana Tata Bangunan Dan Lingkungan Kawasan Arteri Pusat Kota Bandar Lampung Tahun Anggaran 1996/1997. Pemda Kotamadya Daerah Tingkat II Bandar Lampung.

Undang-undang Nomor 23 Tahun 1997 Tentang Pengelolaan Lingkungan Hidup

Undang-undang Nomor 22 Tahun 1999 Tentang Pemerintahan Daerah.
Peraturan Pemerintahan Nomor 27 Tahun 1999 Tentang Analisis Mengenai Dampak Lingkungan

Harian Radar Lampung, Senin 20 Agustus 2001. 